\title{
Antioxidant potential of Sutherlandia frutescens and its protective effects against oxidative stress in various cell cultures
}

\author{
Shakila Tobwala ${ }^{1 \dagger}$, Weili Fan ${ }^{1 \dagger}$, Connor J Hines ${ }^{1}$, William R Folk ${ }^{2}$ and Nuran Ercal ${ }^{* *}$
}

\begin{abstract}
Background: Sutherlandia frutescens (L.) R.Br. (SF) is a South African plant that is widely used to treat stress, infections, cancer, and chronic diseases, many of which involve oxidative stress. The aim of the study was to quantitatively assess the antioxidant potential of SF extracts in cell-free system as well as in cell lines.
\end{abstract}

Methods: Dried SF vegetative parts were extracted using six different solvents, and the extracts were assessed for total phenolic and flavonoid contents, total reducing power, iron chelating capacity, and free radical scavenging power, including, scavenging of hydroxyl radicals, superoxide anions, nitric oxide, and hydrogen peroxide. We further investigated the freeze-dried hot water extract of SF (SFE) to assess its effect against oxidative stress induced by tert-butyl hydroperoxide (t-BHP), an organic peroxide. Three different cell lines: Chinese hamster ovary (CHO), human hepatoma (HepaRG), and human pulmonary alveolar carcinoma (A549) cells, were employed to determine cell viability, intracellular reactive oxygen species (ROS) levels, and reduced to oxidized glutathione levels (GSH/GSSG).

Results: The results indicated that: (1) SF extracts have significant antioxidant potential that is dependent upon the nature of the extraction solvent and (2) SFE protects against tBHP-induced oxidative stress in cells by scavenging ROS and preserving intracellular GSH/GSSG.

Conclusion: Oxidative stress is implicated in a number of disorders, and due to the public's concerns about synthetic antioxidants, various natural antioxidants are being explored for their therapeutic potential. Our findings support claims for $S$. frutescens being a promising adjunctive therapeutic for oxidative stress-related health problems.

Keywords: Sutherlandia frutescens, Oxidative stress, Antioxidant, Glutathione, Radical scavenging, Reactive oxygen species

\section{Background}

Oxidative stress, the imbalance between antioxidant defense and oxidant production in cells, is implicated in the onset and progression of many health problems $[1,2]$. One of the important effects of oxidative stress and free radical generation is decreased levels of cellular antioxidants. Changes in the redox state may affect signaling pathways for biologic processes and disrupt cellular functions.

A logical approach to treating oxidative stress-related disorders is the use of exogenous antioxidants. Many

\footnotetext{
* Correspondence: nercal@mst.edu

${ }^{\dagger}$ Equal contributors

'Department of Chemistry, Missouri University of Science and Technology,

400 West 11th Street, 142 Schrenk Hall, Rolla, MO 65409, USA
}

Full list of author information is available at the end of the article studies have been undertaken to evaluate the efficacy of synthetic and naturally occurring antioxidants in combating the damaging effects of free radicals and reactive oxygen species (ROS), and herbal antioxidants are of special interest to the public because of the perception of their lower toxicities compared to synthetic candidates [3]. The majority of natural antioxidants are polyphenols, which exhibit powerful antioxidant activity by acting as free radical scavengers, hydrogen donors, singlet oxygen quenchers, and metal ion chelators, in addition to inducing gene expressions of antioxidant enzymes [4-6].

Sutherlandia frutescens (SF) has been traditionally used in Africa in the treatment of a wide variety of stress related ailments, including cancer, diabetes, infections, and HIV/AIDS [7]. Phytochemical investigations of this plant 
showed that it contains significant amounts of gamma amino butyric acid and L-canavanine, pinitol, flavonol glycosides, and triterpenoid saponins [7], that may be pharmacologically relevant.

Flavonoids, the largest family of polyphenolic compounds, protect plants against parasites, oxidative injury, and harsh climatic conditions. They are divided into several subclasses: anthocyanins, flavanols, flavanones, flavonols, flavones, and isoflavones. Flavonoids exert their effects by neutralizing or chelating different types of radicals [8-10] and the position of hydroxyl groups and other features of the chemical structure are important for their antioxidant and free radical scavenging activities. Four 3-hydroxy-3-methylglutaroyl-containing flavonol glycosides, known as sutherlandins A - D have been isolated from SF [11].

The antioxidant potential of SF has been reported previously; however, it has not been extensively studied: Fernandes et al. reported that hot water extract of SF scavenges superoxide $\left(\mathrm{O}_{2}{ }^{-}\right)$and hydrogen peroxide $\left(\mathrm{H}_{2} \mathrm{O}_{2}\right)$ in a cell-free system, as well as in presence of human neutrophils [12]: in addition, Katerere and Eloff investigated the antibacterial and antioxidant activity of SF [13], and Koleva et al. reported substantial radical scavenging activity by SF extracts [14].

The therapeutic claims made about SF for a wide variety of ailments inspired us to evaluate its antioxidant potential. In the present study, dried vegetative parts of SF were extracted by methanol, ethanol, acetone, acetonitrile, hot water, and cold water homogenization. To quantitatively assess the antioxidant potential of SF extracts, we used several tests in cell-free systems as well as in cell cultures. The extracts were examined for different ROS scavenging activities, including hydroxyl, superoxide, nitric oxide, and hydrogen peroxide, in addition to total phenolic and flavonoid content, iron chelating capacity, and reducing power. We further investigated the freeze-dried hot water extracts of SF (SFE) to assess effects on cell viability, intracellular ROS levels, and GSH/GSSG ratios of Chinese hamster ovary (CHO), human hepatoma (HepaRG), and human pulmonary alveolar carcinoma (A549) cells. These findings support claims for SF having the potential as an herbal antioxidant.

\section{Methods}

\section{Chemicals}

All chemicals used for analytical purposes were obtained from Sigma (St. Louis, MO) and Fisher Scientific (Fair Lawn, NJ). The human hepatoma cells (HepaRG) were obtained from Invitrogen. Chinese hamster ovary $(\mathrm{CHO})$ K1 and the human lung carcinoma pulmonary type IIlike epithelium cells were obtained from American Type Culture Collection (ATCC) (Manassas, VA, USA).

\section{Preparation of plant extracts}

Dried, milled vegetative parts of Sutherlandia frutescens (family: Fabaceae/Leguminosa), obtained from Big Tree Nutraceutical, Fish Hoek, South Africa were extracted in six different solvents: methanol, ethanol, acetone, acetonitrile, hot water, and cold water homogenization. Briefly, $1 \mathrm{~g}$ of dried SF was extracted in $50 \mathrm{ml}$ of each solvent. Extraction in methanol, ethanol, acetone, and acetonitrile was done by adding respective solvent to the SF, followed by sonication for $20 \mathrm{~min}$. Hot water extract was prepared by boiling SF for $20 \mathrm{~min}$ and cooling to room temperature. Cold water extract was prepared by homogenizing SF in water by tissue tearor (Biospec Products) for $20 \mathrm{~min}$. All extracts were vacuum filtered and thereafter stored at $4^{\circ} \mathrm{C}$ until further use $(20 \mathrm{mg} /$ $\mathrm{ml})$. For studies in cells, however, the hot water filtrate was freeze-dried for $72 \mathrm{~h}$ in the Savant refrigerated vapor trap (RVT4104-180) to obtain a dried powdered plant extract. Lyophilized extract was then dissolved in a serum-free media to a final concentration of $1 \mathrm{mg} / \mathrm{ml}$ stock solution, referred as a SFE (a yield of 5\%).

\section{Determination of total polyphenolic content}

Total phenolic content of the SF extract was determined, as described by Konaté et al. with minor modifications [15], which rely on the formation of a bluish-grey complex between Folin-Ciocalteu reagent ( $\mathrm{F}-\mathrm{C}$ reagent) with phenols. Briefly, $125 \mu \mathrm{l}$ of the plant extract was mixed with $625 \mu \mathrm{l}$ of F-C reagent (10-fold diluted) and incubated at room temperature for $5 \mathrm{~min}$, followed by the addition of $500 \mu \mathrm{l}$ of $75 \mathrm{mg} / \mathrm{ml} \mathrm{Na}_{2} \mathrm{CO}_{3}$ solution. The mixture was vortexed and incubated at room temperature in the dark for $90 \mathrm{~min}$. The absorbance at $760 \mathrm{~nm}$ was measured against a reagent blank, with gallic acid used as the standard. The results were expressed as $\mu \mathrm{g}$ of gallic acid equivalents (GAE)/mg of dried plant material.

\section{Determination of total flavonoid content}

Determination of the total flavonoid content of the extracts, which was as described by Kalava et al. with minor modifications, relied on the formation of an acidstable, bright yellow complex between aluminum chloride and flavones/flavonoids [16]. In brief, $200 \mu \mathrm{l}$ of plant extract was mixed with a solution of $60 \mu \mathrm{l}$ of $5 \% \mathrm{NaNO}_{2}$ and $800 \mu \mathrm{l}$ of deionized water, and vortexed, then allowed to stand at room temperature for $5 \mathrm{~min}$ in the dark. Thereafter, $60 \mu \mathrm{l}$ of $10 \% \mathrm{AlCl}_{3}$ were added to the mixture, followed by $5 \mathrm{~min}$ of incubation at room temperature in the dark. The color was developed by adding $400 \mu \mathrm{l}$ of $1 \mathrm{M} \mathrm{NaOH}$ and $\mathrm{A}_{415} \mathrm{~nm}$ was measured against a reagent blank with quercetin as a standard. The concentrations of phenols in the test samples were calculated from the calibration plot and expressed as $\mu \mathrm{g}$ of quercetin equivalents $(\mathrm{QE}) / \mathrm{mg}$ of dried plant leaves. 


\section{Determination of total reducing power}

Total reducing power of the SF extracts was determined according to the method of Jayanthi et al. [17]; a solution comprising $2.5 \mathrm{ml}$ of $0.2 \mathrm{M}$ phosphate buffer ( $\mathrm{pH} 6.6$ ) and $2.5 \mathrm{ml}$ of $1 \%$ potassium ferricyanide were added to $1 \mathrm{ml}$ plant extract and gently mixed. The mixtures were incubated at $50{ }^{\circ} \mathrm{C}$ in a water bath for $20 \mathrm{~min}$, then mixed with $2.5 \mathrm{ml}$ of $10 \%$ trichloroacetic acid (TCA) and centrifuged at 6,000 rpm for $10 \mathrm{~min}$. From the top layer, $2.5 \mathrm{ml}$ were transferred into tubes containing $2.5 \mathrm{ml}$ distilled water and $0.5 \mathrm{ml}$ of $0.1 \%$ ferric chloride $\left(\mathrm{FeCl}_{3} \cdot 6 \mathrm{H}_{2} \mathrm{O}\right)$. The resulting solutions were mixed well and, after $5 \mathrm{~min}$, the absorbance was measured at $700 \mathrm{~nm}$ with ascorbic acid as the standard. Results were expressed as milligrams of ascorbic acid equivalent (AAE)/mg of dried plant material.

\section{Determination of radical scavenging power}

The radical scavenging power of extracts was assessed by the method of Shyamala et al. [18] with slight modifications. The reaction mixture had a total volume of $3 \mathrm{ml}$, which included $2.9 \mathrm{ml}$ of DPPH $\left(1 \times 10^{-4} \mathrm{M}\right.$ $\mathrm{DPPH}$ ) and $0.1 \mathrm{ml}$ of the corresponding sample at various concentrations. The solutions were left in the dark, at room temperature for $30 \mathrm{~min}$, and the resulting absorbance at $520 \mathrm{~nm}$ was measured against blanks. Decrease in intensity corresponded to a higher radical scavenging power, calculated as $[1-A 1 \div A 2] \times 100 \%$, whereas A1 and A2 are the absorbance with and without plant extract, respectively. Butylated hydroxytoluene (BHT) was used as the standard.

\section{Determination of $\mathrm{H}_{2} \mathrm{O}_{2}$ scavenging power}

The $\mathrm{H}_{2} \mathrm{O}_{2}$ scavenging power of the extracts was determined as described by Ozyurek et al. with modifications [19], based on the complex between neocupronine, a cuprous ion-specific chromogen, and cuprous ion, the reduction product of cupric ion by hydrogen peroxide. In brief, $500 \mu \mathrm{l}$ phosphate buffer (200 mM; pH = 7.4), 400 $\mu \mathrm{l}$ of $10 \mathrm{mM} \mathrm{H}_{2} \mathrm{O}_{2}$ or deionized water, $200 \mu \mathrm{l}$ of extract or solvent, and $400 \mu \mathrm{l}$ of $0.1 \mathrm{mM} \mathrm{CuCl} 2$ were mixed and incubated at $37^{\circ} \mathrm{C}$ for $30 \mathrm{~min}$. Then, $400 \mu \mathrm{l}$ of deionized water were added and $500 \mu \mathrm{l}$ of this solution was added to a mixture of $1 \mathrm{ml}$ of $10 \mathrm{mM} \mathrm{CuCl}_{2}, 1 \mathrm{ml}$ of $7.5 \mathrm{mM}$ neocupronine, and $2 \mathrm{ml}$ of $1 \mathrm{M} \mathrm{NH}_{4} \mathrm{Ac}$. Absorbance was measured at $450 \mathrm{~nm}$ and the hydrogen peroxide scavenging power was calculated as $[1-(A 1 \div A 2) / A 0] \times 100 \%$, where $\mathrm{A} 0$ was the absorbance of the mixture without extract but with $\mathrm{H}_{2} \mathrm{O}_{2}$, A1 was that with both the extract and $\mathrm{H}_{2} \mathrm{O}_{2}$ and $\mathrm{A} 2$ was that with extract but without $\mathrm{H}_{2} \mathrm{O}_{2}$. Pyruvate was used as the standard.

\section{Determination of nitric oxide scavenging power}

Nitric oxide scavenging power of the plant extract was determined as described by Kumar et al. [20] with slight modifications, was based on the formation of a diazo compound between Griess Reagent and nitrate, the oxidation product of nitric oxide released by sodium nitroprusside. Briefly, $1 \mathrm{ml}$ of the extract or solvent was mixed with $0.3 \mathrm{ml}$ of $60 \mathrm{mM}$ sodium nitroprusside, and illuminated under fluorescent light at room temperature for $150 \mathrm{~min}$. Thereafter, $0.5 \mathrm{ml}$ of Griess Reagent [1\% sulfanilamide, $2 \%$ phosphoric acid and $0.1 \% \mathrm{~N}-(1-$ naphthyl)-ethylenediamine $2 \mathrm{HCl}$ ] or deionized water was added. Absorbance was measured at $546 \mathrm{~nm}$ and nitric oxide scavenging power was calculated as $[1-(A 1 \div A 2) /$ $A 0] \times 100 \%$ where A0 is the absorbance of the mixture without extract, A1 is the absorbance with both, and A2 is the absorbance with extract and without Griess Reagent. Curcumin was used as the standard.

\section{Determination of $\mathrm{O}_{2}^{-}$scavenging power}

The $\mathrm{O}_{2}{ }^{-}$scavenging power of the extract, determined as described by Bajpai et al. [21] with slight modifications, was based on reduction of nitroblue tetrazolium (NBT) to a purple product by superoxide anion, which was generated via a redox cycle by 5-methylphenazinium methyl sulfate (PMS). In brief, $1 \mathrm{ml}$ of 156 $\mu \mathrm{M}$ NBT (in $100 \mathrm{mM}$ phosphate buffer, $\mathrm{pH}$ 7.4) or buffer alone, $1 \mathrm{ml}$ of $486 \mu \mathrm{M}$ NADH (in buffer) or buffer, and $100 \mu \mathrm{l}$ of extract or solvent were mixed. $100 \mu \mathrm{l}$ of $330 \mu \mathrm{M}$ PMS (in buffer) or buffer alone were added and the mixture was incubated at room temperature for 5 min. Absorbance was measured at $560 \mathrm{~nm}$ and the superoxide scavenging power was calculated as [1 $(A 1 \div A 2) / A 0] \times 100 \%$, where $\mathrm{A} 0$ is the absorbance of the mixture without extract but with $\mathrm{NBT} / \mathrm{NADH}, \mathrm{A} 1$ is the absorbance with extract and NBT/NADH and A2 is the absorbance with extract and without NBT/NADH. Quercetin was used as the standard.

\section{Determination of ${ }^{\circ} \mathrm{OH}$ scavenging power}

The ${ }^{\circ} \mathrm{OH}$ scavenging power of the extracts was determined as described by Kunchandy et al. [22] with slight modification, was based on the formation of a complex between thio barbituric acid (TBA) and the oxidation product of 2-deoxyribose by hydroxyl radicals. In brief, $100 \mu \mathrm{l}$ of $28 \mathrm{mM}$ 2-deoxyribose or deionized water, as well as $500 \mu \mathrm{l}$ of $20 \mathrm{mM}$ phosphate buffer ( $\mathrm{pH}$ 7.4) were added to $100 \mu \mathrm{l}$ extract or solvent. Thereafter, $100 \mu \mathrm{l}$ of $1 \mathrm{mM} \mathrm{FeSO}, 100 \mu \mathrm{l}$ of $1 \mathrm{mM}$ EDTA tetrasodium salt, and $100 \mu \mathrm{l}$ of $10 \mathrm{mM} \mathrm{H}_{2} \mathrm{O}_{2}$ were added to the mixture, which was incubated at $37^{\circ} \mathrm{C}$ for $1 \mathrm{~h}$. Then, $2 \mathrm{ml}$ of $2.8 \%$ TCA and $2 \mathrm{ml}$ of $1 \%$ TBA were added. This mixture was boiled for $15 \mathrm{~min}$ and allowed to cool to room temperature and $\mathrm{A}_{532 \mathrm{~nm}}$ measured. Hydroxyl radical scavenging power of the extract was calculated as $[1$ $(A 1 \div A 2) / A 0] \times 100 \%$ where $\mathrm{A} 0$ is the absorbance of the mixture without extract but with deoxyribose, A1 is the 
absorbance with both, and A2 is the absorbance without deoxyribose but with extract. Mannitol was used as the standard.

\section{Determination of iron $\left(\mathrm{Fe}^{2+}\right)$ - chelating power}

The iron-chelating power of the extracts, based on the reaction between ferrous ion and ferrozine was determined as described by Ercal et al. [23] with minor modifications. In brief, $100 \mu \mathrm{l}$ of the extract (or solvent) were mixed with $100 \mu \mathrm{l}$ of $0.6 \mathrm{mM} \mathrm{FeSO}_{4}$ and $1.7 \mathrm{ml}$ of deionized water and incubated at room temperature for 5 min in the dark. Afterwards, $100 \mu \mathrm{l}$ of a $5 \mathrm{mM}$ ferrozine solution (in methanol or methanol) were added to the mixture and incubated for $5 \mathrm{~min}$ in the dark. Absorbance at $562 \mathrm{~nm}$ was measured and the chelating power of the plant extract was calculated as $[1-(A 1 \div A 2) / A 0] \times$ $100 \%$, where A0 is the absorbance of the control (without extract), A1 is the absorbance in the presence of the extract and A2 is the absorbance without ferrozine. EDTA tetrasodium salt was used as the standard.

\section{Cell culture}

The human lung carcinoma pulmonary type II-like epithelium cells (A549) were seeded in $25 \mathrm{~cm}^{2}$ flasks coated with type 1 rat tail collagen (Sigma-Aldrich, St. Louis, MO) and maintained in F-12 Ham's medium with 10\% heat-inactivated fetal bovine serum in humidified $5 \%$ $\mathrm{CO}_{2} / 95 \%$ air at $37^{\circ} \mathrm{C}$. The culture medium was changed every 3 days.

Human hepatoma cells (HepaRG) were seeded in 75 $\mathrm{cm}^{2}$ flasks coated with type 1 rat tail collagen (SigmaAldrich, St. Louis, MO) and maintained in William's E medium supplemented with 10\% FCS, $100 \mathrm{U}$ penicillin, $100 \mu \mathrm{g} / \mathrm{ml}$ streptomycin, $5 \mathrm{ug} / \mathrm{ml}$ insulin, and hydrocortisone in humidified $5 \% \mathrm{CO} 2 / 95 \%$ air at $37^{\circ} \mathrm{C}$. The culture medium was renewed every 3 days. After about 2 weeks, when the cells were confluent they were shifted to the same medium supplemented with $2 \%$ DMSO (differentiation medium). The medium was renewed every 2 to 3 days for 2 more weeks, then switched to a DMSO-free medium for 1 day prior to the cells being used for assays.

Chinese hamster ovary $(\mathrm{CHO}) \mathrm{K} 1$ cells were grown in Ham's F-12 culture medium, supplemented with $10 \%$ (v/v) fetal bovine serum (FBS), and $2 \mathrm{mM}$ L-glutamine, $100 \mathrm{U} / \mathrm{ml}$ penicillin and $100 \mu \mathrm{g} / \mathrm{ml}$ streptomycin. The cells were maintained in a humidified incubator at $37^{\circ} \mathrm{C}$ and supplied with $95 \% \mathrm{O}_{2}$ and $5 \% \mathrm{CO}_{2}$.

\section{Determination of cell viability}

Cells were seeded in 96-well plates at a density of approximately $1.25 \times 10^{4}$ cells/well, for a day. To assess cytotoxicity of the SF extract, the cells were incubated with concentrations of SFE, ranging from $10 \mu \mathrm{g} / \mathrm{ml}$ to 1 $\mathrm{mg} / \mathrm{ml}$, in serum-free medium for $24 \mathrm{~h}$. To assess cytotoxicity of $\mathrm{t}$-BHP, the media were replaced by various concentrations of t-BHP $(10 \mu \mathrm{M}$ to $500 \mu \mathrm{M})$ in serumfree medium for $24 \mathrm{~h}$. The protective effects of SFE were assessed by pretreating cells with $500 \mu \mathrm{g} / \mathrm{ml}$ of SFE for 2 $\mathrm{h}$, followed by treatment with t-BHP for $24 \mathrm{~h}$. After $24 \mathrm{~h}$ of $\mathrm{t}$-BHP treatment, the medium was discarded and viability assessed with a Calcein AM assay KIT (Biotium, Inc. CA). The cells were washed three times with PBS, and $100 \mu \mathrm{l}$ of $2.0 \mu \mathrm{M}$ Calcein AM in PBS were added to each well for $30 \mathrm{~min}$ at $37^{\circ} \mathrm{C}$. The fluorescence was measured with an excitation wavelength at $485 \mathrm{~nm}$ and an emission wavelength of $530 \mathrm{~nm}$, using a microplate reader (FLUOstar, BMG Labtechnologies, Durham, NC, USA).

\section{Measurement of intracellular ROS levels}

Intracellular ROS generation was measured using a well-characterized probe, 2', 7'-dichlorodihydrofluorescein diacetate $\left(\mathrm{H}_{2} \mathrm{DCF}-\mathrm{DA}\right)$ (Wang and Joseph, 1999). In brief, $\mathrm{H}_{2}$ DCF-DA is diffused into cells and is deacetylated by cellular esterases to non-fluorescent 2', 7'dichlorodihydrofluorescein, which is rapidly oxidized to highly fluorescent 2', 7'-dichlorofluorescein (DCF) by ROS. The fluorescence intensity is proportional to the ROS levels within the cell cytosol. In the groups with SFE pretreatment, media containing various concentrations of SFE was added and incubated for $2 \mathrm{~h}$. Once pretreated, the cells were washed twice with PBS and incubated with a solution of $50 \mu \mathrm{M} \mathrm{H}_{2}$ DCF-DA in phenol red free media for $30 \mathrm{~min}$. This was followed by washing the cells twice with PBS. The respective groups were then dosed either with $\mathrm{t}$-BHP or plain media for $24 \mathrm{~h}$ and fluorescence was determined at $485 \mathrm{~nm}$ excitation and $520 \mathrm{~nm}$ emission, using a microplate reader (FLUOstar, BMG Labtechnologies, Durham, NC, USA).

\section{Determination of intracellular glutathione (GSH) levels}

Intracellular GSH content was determined by reverse phase HPLC. The protective effects of SFE were studied by pretreating cells with $500 \mu \mathrm{g} / \mathrm{ml}$ of SFE for $2 \mathrm{~h}$, followed by treatment with $\mathrm{t}$-BHP for $24 \mathrm{~h}$. All cell samples were homogenized in SBB. Twenty microliters of this homogenate were added to $230 \mu \mathrm{l}$ of HPLC grade water and $750 \mu \mathrm{l}$ of NPM (1 mM in acetonitrile). The resulting solutions were incubated at room temperature for $5 \mathrm{~min}$. The reaction was stopped by adding $10 \mu \mathrm{l}$ of $2 \mathrm{~N} \mathrm{HCl}$. The samples were filtered through a $0.45 \mu \mathrm{m}$ filter (Advantec MFS, Inc. Dulin, CA, USA) and injected onto the HPLC system. $5 \mu \mathrm{l}$ of the sample were injected for analysis using a Thermo Finnigan TM Spectra SYSTEM SCM1000 Vacuum Membrane Degasser, Finnigan TM SpectraSYSTEM P2000 Gradient Pump, Finnigan TM SpectraSYSTEM AS3000 Autosampler, and 
FinniganTM SpectraSYSTEM FL3000 Fluorescence Detector $(\lambda e x=330 \mathrm{~nm}$ and $\lambda \mathrm{em}=376 \mathrm{~nm})$. The HPLC column was a Reliasil ODS-1 C18 column (Column Engineering, Ontario, CA, USA). The mobile phase was $70 \%$ acetonitrile and $30 \%$ water and was adjusted to a $\mathrm{pH}$ of 2.5 through the addition of $1 \mathrm{ml} / \mathrm{L}$ of both acetic and o-phosphoric acids. The NPM derivatives were eluted from the column isocratically at a flow rate of $1 \mathrm{ml} / \mathrm{min}$.

\section{Determination of glutathione disulfide (GSSG) levels}

Total glutathione content was determined by reverse phase HPLC. Cell samples were homogenized in SBB. Twenty microliters of this homogenate were added to 60 $\mu \mathrm{l}$ of NADPH $(2 \mathrm{mg} / \mathrm{ml})$ in nanopure water and $20 \mu \mathrm{l}$ of 1 unit/ml glutathione reductase were added to reduce GSSG. After $10 \mathrm{~min}$ of incubation at room temperature, the treated samples were diluted with $150 \mu \mathrm{H} \mathrm{H}_{2} \mathrm{O}$, and then immediately derivatized with $750 \mu \mathrm{l}$ of $1.0 \mathrm{mM}$ NPM. The samples were analyzed by reverse phase HPLC as detailed for the determination of GSH. Data from the original and total current GSH levels in each sample were subsequently used to calculate the levels of GSSG present in each sample.

\section{Determination of protein}

Protein levels of the cell samples were measured using the Bradford method [24]. Concentrated Coomassie blue (Bio-Rad,Hercules, CA, USA) was diluted 1:5 (v/v) with distilled water and $1.5 \mathrm{ml}$ added to $50 \mu \mathrm{l}$ of diluted cell homogenate; the solution was vortexed and allowed to stand at room temperature for $10 \mathrm{~min}$ and the absorbance was measured at $595 \mathrm{~nm}$ using bovine serum albumin as the protein standard.

\section{Statistical analysis}

All reported values were represented as the mean \pm S.D $(\mathrm{n}=4)$. Statistical analyses was performed using GraphPad Prism software (GraphPad, San Diego, CA). Statistical significance was ascertained by one way analysis of variance, followed by Tukey's multiple comparison tests. Values of $\mathrm{p}<0.05$ were considered significant.

\section{Results}

\section{Total phenolic content}

Total phenolic content, expressed as $\mu \mathrm{g}$ gallic acid equivalent/mg dried SF, was determined by the polarity of the extraction solvent with the following order (from high to low): Hot water $>$ cold water $>$ methanol $>$ ethanol $>$ acetone $>$ acetonitrile (Table 1). Hot water appears to be the best extraction solvent for polyphenols with the total phenolic content of hot water extract being $12.9 \pm 0.17 \mu \mathrm{g}$ gallic acid equivalent/mg of dried SF.
Table 1 Total polyphenolic content, flavonoid contents, and reducing power of various extracts of Sutherlandia Frutescens

\begin{tabular}{llll}
\hline Extract & $\begin{array}{l}\text { Total Polyphenolic } \\
\text { Content (GAE, in } \\
\boldsymbol{\mu} \mathbf{g} / \mathbf{m g} \text { of dried } \\
\text { leaves) }\end{array}$ & $\begin{array}{l}\text { Flavonoid Content } \\
(\mathbf{Q E}, \text { in } \boldsymbol{\mu g} / \mathbf{m g} \\
\text { of dried leaves) }\end{array}$ & $\begin{array}{l}\text { Total Reducing } \\
\text { Power (AAE, } \\
\text { in } \boldsymbol{\mu g} / \mathbf{m g} \text { of } \\
\mathbf{d r i e d} \text { leaves) }\end{array}$ \\
\hline Hot water & $12.9 \pm 0.17$ & $28.7 \pm 0.32$ & $8.63 \pm 0.17$ \\
Cold water & $11.3 \pm 0.32^{\mathrm{a}}$ & $17.5 \pm 0.50^{\mathrm{a}}$ & $7.74 \pm 0.09^{\mathrm{a}}$ \\
Methanol & $9.26 \pm 0.18^{\mathrm{ab}}$ & $24.7 \pm 0.32^{\mathrm{ab}}$ & $7.10 \pm 0.47^{\mathrm{ab}}$ \\
Ethanol & $4.66 \pm 0.13^{\mathrm{abc}}$ & $17.0 \pm 0.41^{\mathrm{ac}}$ & $2.06 \pm 0.09^{\mathrm{abc}}$ \\
Acetone & $2.29 \pm 0.16^{\mathrm{abcd}}$ & $9.33 \pm 0.38^{\mathrm{abcd}}$ & $0.98 \pm 0.16^{\mathrm{abcd}}$ \\
Acetonitrile & $1.57 \pm 0.01^{\mathrm{abcde}}$ & $6.08 \pm 0.18^{\mathrm{abcde}}$ & $0.68 \pm 0.05^{\mathrm{abcd}}$ \\
\hline
\end{tabular}

All experiments were performed in quadruplicates, and the values reported are mean $\pm S D$. (a: different from hot water extract, b: different from cold water extract, c: different from methanol extract, $\mathrm{d}$ : different from ethanol extract, e: different from acetone extract, $\mathrm{p}<0.05$ ).

\section{Total flavonoid content}

Similar to the phenolic content, the total flavonoid content was affected by the polarity of the extraction solvent with the following order: hot water $>$ methanol $>$ cold water/homogenization $\geq$ ethanol $>$ acetone $>$ acetonitrile (Table 1). The total flavonoid content of the hot water extract of SF was $28.7 \pm 0.324 \mu \mathrm{g}$ quercetin equivalent/ mg of dried SF.

\section{Reducing power}

Reducing power is associated with antioxidant activity and may serve as an important index of the antioxidant potential. Reducing power characteristics of different solvent extracts of SF are summarized in Table 1 in the following order: hot water $>$ cold water $>$ methanol $>$ ethanol $>$ acetone $>$ acetonitrile. Total reducing power of hot water extract was $8.63 \mu \mathrm{g}$ ascorbic acid equivalent/mg of dried SF, only 1.11 times higher than that of cold waterhomogenization and 1.21 times higher than methanol extract. In contrast, the values of ethanol, acetone, and acetonitrile were 4.19 times, 8.80 times and 12.74 times lower than that of hot water extract, respectively.

\section{Radical scavenging power}

Free radical scavenging power is an important property for consideration in evaluating the protective effects of an antioxidant because of the deleterious effects of radicals in biological systems. The DPPH scavenging method is a simple method for assessing the radical scavenging power of a compound [25], and is based on the ability of antioxidants to reduce the $\mathrm{DPPH}$ radical to a more stable DPPHH form. In the presence of a free radical scavenger, $\mathrm{DPPH}$ is reduced with a corresponding decrease in absorbance. BHT, a derivative of phenol and a functionally synthetic analogue of Vitamin E that suppresses autoxidation, was used as the standard. The DPPH scavenging activities of different SF extracts (Figure 1) are affected by 


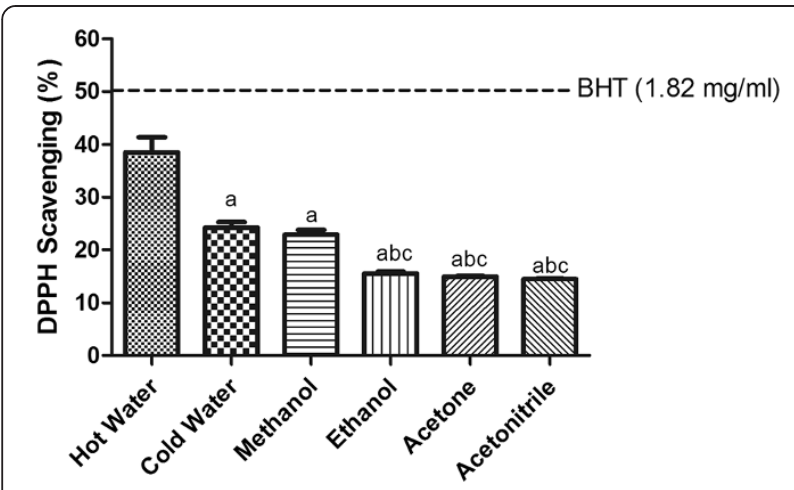

Figure 1 The DPPH radical-scavenging activity of SF extracts. The absorbance values were converted to the scavenging effect (\%) and data plotted as the means of the replicate scavenging effect (\%) values \pm S.D. $(n=4)$. The $I C_{50}$ value of the reference compound BHT was $1.82 \mathrm{mg} / \mathrm{ml}$. The concentration of SF extract was $20 \mathrm{mg}$ of dried leaves $/ \mathrm{ml}$. (a: different from hot water extract, b: different from cold water extract, c: different from methanol extract, d: different from ethanol extract, e: different from acetone extract, $p<0.05$ ). the extraction solvent as follows: hot water $>$ cold water $>$ methanol $>$ ethanol $\geq$ acetone $\geq$ acetonitrile. Hot water extract possessed the highest radical scavenging ability (39\%) among all SF extracts.

\section{$\mathrm{H}_{2} \mathrm{O}_{2}$ scavenging capacity}

$\mathrm{H}_{2} \mathrm{O}_{2}$ is not a direct reactive oxygen species but, due to its high membrane permeability, it enters cells and leads to the production of hydroxyl radicals and superoxide radicals in the presence of metal ions. Thus, an important measure of the antioxidant activity of a compound is its scavenging activity for $\mathrm{H}_{2} \mathrm{O}_{2}$. As compared with sodium pyruvate, the $\mathrm{H}_{2} \mathrm{O}_{2}$ scavenging power of extracts was: hot water $>$ cold water $>$ methanol $>$ ethanol $\geq$ acetone $>$ acetonitrile (Figure 2).

\section{-OH scavenging capacity}

- $\mathrm{OH}$ radicals are short lived and can be highly deleterious to cell membranes and other biomolecules. ${ }^{\circ} \mathrm{OH}$ radical scavenging is therefore necessary to protect cells from oxidative damage. Of the many different ways by which ${ }^{\circ} \mathrm{OH}$ radicals can be produced, the most important is the Fenton reaction, which involves the transition metal catalyzed decomposition of hydrogen peroxide to produce hydroxyl radicals [26]. Mannitol was used as a standard antioxidant for comparison, with the hydroxyl radical scavenging capacity of extracts following the order: hot water $>$ cold water $>$ methanol $>$ ethanol $>$ acetone $>$ acetonitrile (Figure 3 ).

\section{Superoxide radical anion scavenging capacity}

Superoxide radical anion $\left(\mathrm{O}^{-}\right)$originates from the oneelectron reduction of free molecular oxygen, and

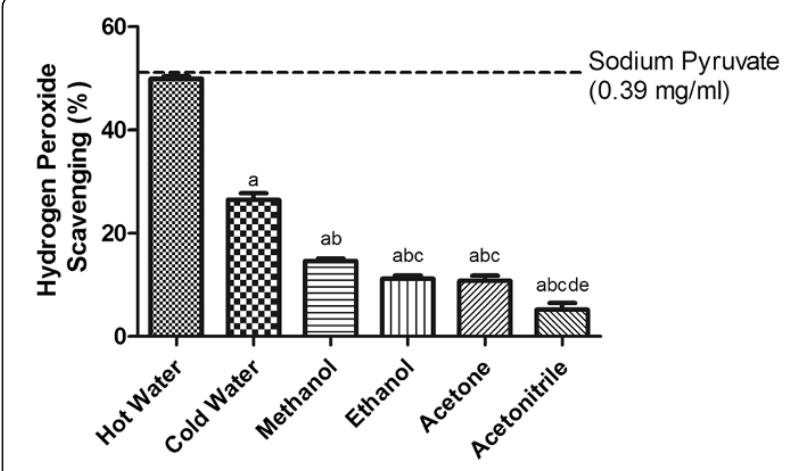

Figure $\mathbf{2}$ The hydrogen peroxide radical-scavenging activity of SF extracts. The absorbance values were converted to the scavenging effect (\%) and data plotted as the means of the replicate scavenging effect $(\%)$ values \pm S.D. $(n=4)$. The $I C_{50}$ value of the reference compound sodium pyruvate was $0.39 \mathrm{mg} / \mathrm{ml}$. The concentration of SF extract was $20 \mathrm{mg}$ of dried leaves $/ \mathrm{ml}$. (a: different from hot water extract, b: different from cold water extract, c: different from methanol extract, $d$ : different from ethanol extract, e: different from acetone extract, $p<0.05$ ).

is implicated in a number of oxidative stress related disorders. The superoxide scavenging activities of the samples (Figure 4) were in the following order (from highest to lowest): hot water > cold water/homogenization $>$ methanol $>$ ethanol $\geq$ acetone $>$ acetonitrile.

\section{Nitric oxide (NO) scavenging capacity}

$\mathrm{NO}$ is a short-lived (half-life 3-30 s) lipophillic colorless gas that can very easily diffuse between cells. Although it does not interact directly with biomolecules, NO can react with oxygen to produce stable intermediates, such as $\mathrm{NO}_{2}, \mathrm{~N}_{2} \mathrm{O}_{4}, \mathrm{~N}_{3} \mathrm{O}_{4}$ [27], and peroxynitrite upon reaction with superoxide [28], which are in turn deleterious. The NO scavenging ability of the extracts followed this order (from high to low): hot water > cold water/ homogenization $\geq$ methanol $\geq$ ethanol $>$ acetone $>$ acetonitrile (Figure 5).

\section{Iron $\left(\mathrm{Fe}^{2+}\right)$ - chelating capacity}

Metal chelating property is especially important because of the ability of transition metal ions like $\mathrm{Fe}^{2+}$ to catalyze a number of free radical generating reactions such as the Fenton reaction. 'OH produced as a result of this reaction can accelerate lipid peroxidation by decomposing lipid hydroperoxides into peroxyl and alkoxyl radicals that can abstract hydrogen, propagate the chain reaction [29], and damage cell membranes. Metal chelating activity is, therefore, an important indicator of the antioxidant capacity of a compound. In the presence of a chelating agent, $\mathrm{Fe}^{2+}$ is no longer available to form a colored complex, as reflected by a decrease in absorbance. The iron chelating ability was in the following order: hot 


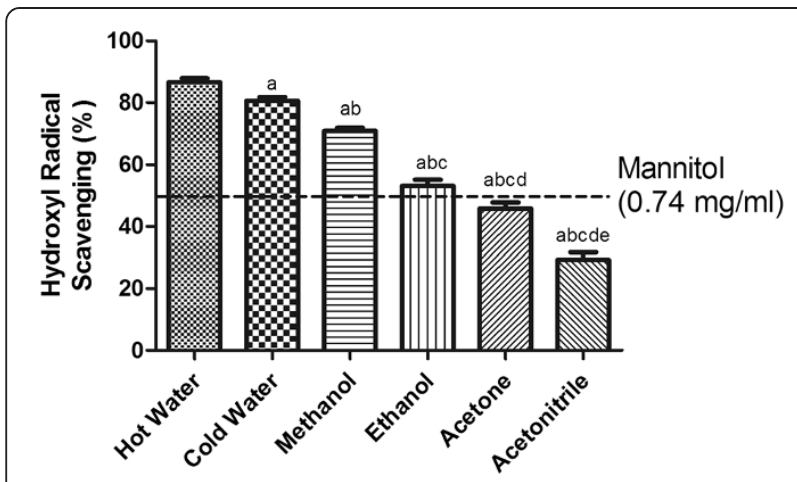

Figure 3 The hydroxyl radical-scavenging activity of SF extracts. The absorbance values were converted to the scavenging effect (\%) and data plotted as the means of the replicate scavenging effect $(\%)$ values \pm S.D. $(n=4)$. The $I C_{50}$ value of the reference compound mannitol was $0.74 \mathrm{mg} / \mathrm{ml}$. The concentration of SF extract was $20 \mathrm{mg}$ of dried leaves $/ \mathrm{ml}$. (a: different from hot water extract, b: different from cold water extract, c: different from methanol extract, $d$ : different from ethanol extract, e: different from acetone extract, $\mathrm{p}<0.05$ ).

water $>$ cold water/homogenization $>$ methanol $>$ ethanol $>$ acetone $>$ acetonitrile (Figure 6).

\section{Cytotoxicity of SFE on A549, HepaRG, and CHO cells}

Since hot water extract appeared to have high antioxidant potential, it was chosen for subsequent cell based studies. SFE was not toxic to $\mathrm{CHO}$ cells or A549 cells up to a concentration of $500 \mu \mathrm{g} / \mathrm{ml}$ for $24 \mathrm{~h}$, however, a decrease in cell viability was observed for HepaRG cells above $100 \mu \mathrm{g} / \mathrm{ml}$ of SFE treatment for $24 \mathrm{~h}$ (Figure 7). This was confirmed using a calcein AM assay.

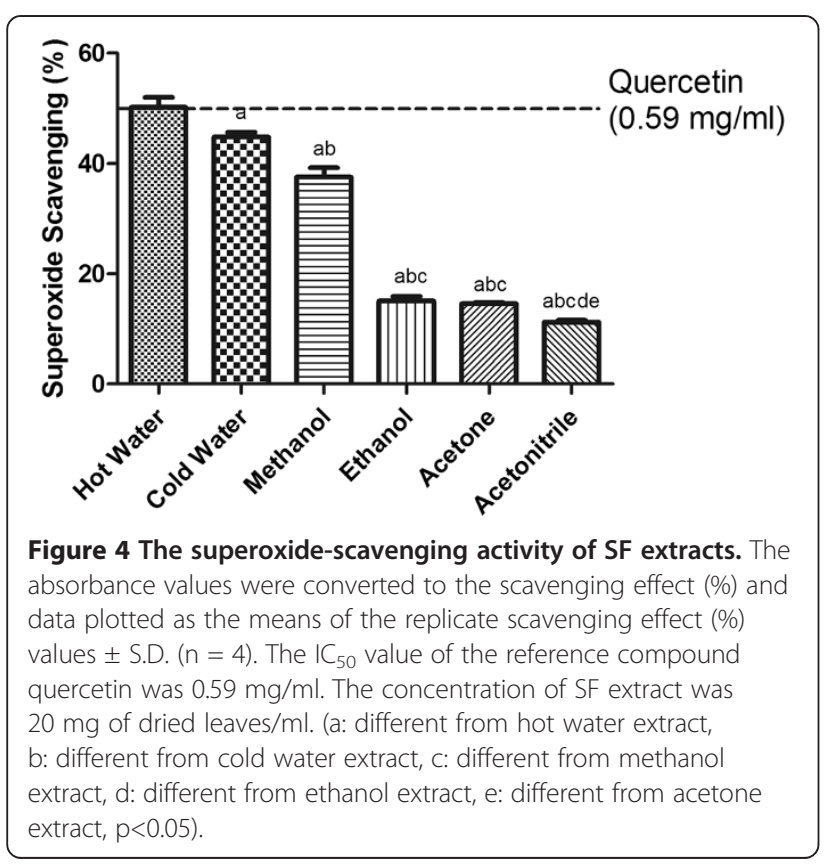

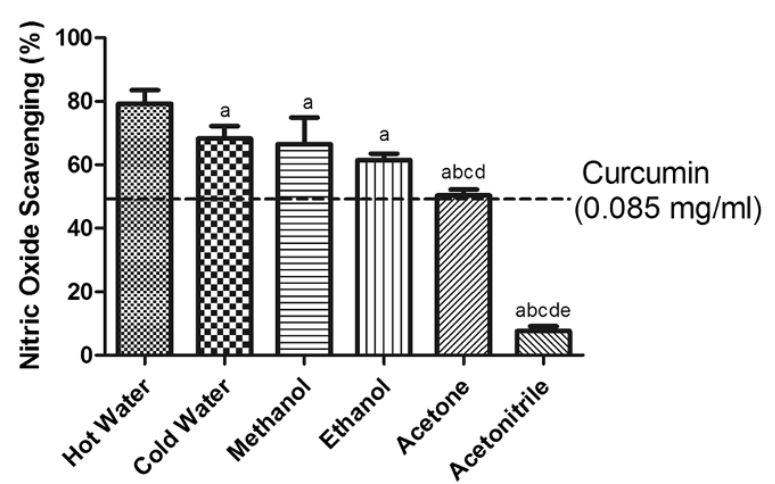

Figure $\mathbf{5}$ The nitric oxide-scavenging activity of SF extracts. The absorbance values were converted to the scavenging effect (\%) and data plotted as the means of the replicate scavenging effect (\%) values \pm S.D. $(n=4)$. The $I C_{50}$ value of the reference compound curcumin was $0.085 \mathrm{mg} / \mathrm{ml}$. The concentration of SF extract was 20 $\mathrm{mg}$ of dried leaves $/ \mathrm{ml}$. (a: different from hot water extract, b: different from cold water extract, c: different from methanol extract, $\mathrm{d}$ : different from ethanol extract, e: different from acetone extract, $p<0.05$ )

\section{Effect of SFE on t-BHP-induced cytotoxicity}

To study the protective effects of SFE on t-BHP-induced toxicity, cells were pretreated with various concentrations of SFE $(10 \mu \mathrm{g} / \mathrm{ml}$ to $1000 \mu \mathrm{g} / \mathrm{ml})$ for $2 \mathrm{~h}$, followed by incubation with $50 \mu \mathrm{M}$ of t-BHP for $24 \mathrm{~h}$. In all three cell lines, cell viability decreased to approximately 40$50 \%$ of the control, when treated with $50 \mu \mathrm{M} \mathrm{t}-\mathrm{BHP}$, which increased significantly in a dose dependent manner to $500 \mu \mathrm{g} / \mathrm{ml}$ upon pretreatment with SFE (Figure 8). However, no further increase was observed upon increasing the concentration to $1000 \mu \mathrm{g} / \mathrm{ml}$. The lowest nontoxic concentration of SFE that provided maximum protection was $500 \mu \mathrm{g} / \mathrm{ml}$ and, therefore, it was chosen

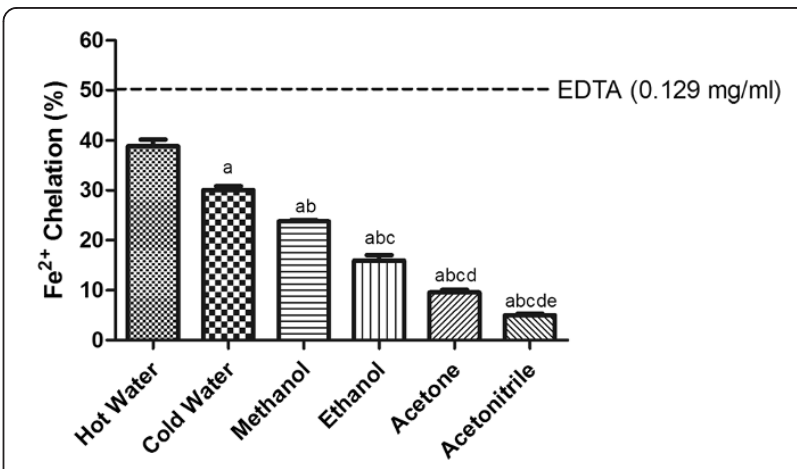

Figure $6 \mathrm{Fe}^{2+}$-chelating activity of SF extracts. The absorbance values were converted to the scavenging effect (\%) and data plotted as the means of the replicate chelating effect (\%) values \pm S.D. $(n=4)$. The $I C_{50}$ value of the reference compound EDTA was $0.129 \mathrm{mg} / \mathrm{ml}$. The concentration of SF extract was $20 \mathrm{mg}$ of dried leaves $/ \mathrm{ml}$. (a: different from hot water extract, b: different from cold water extract, c: different from methanol extract, d: different from ethanol extract, e: different from acetone extract, $\mathrm{p}<0.05$ ). 


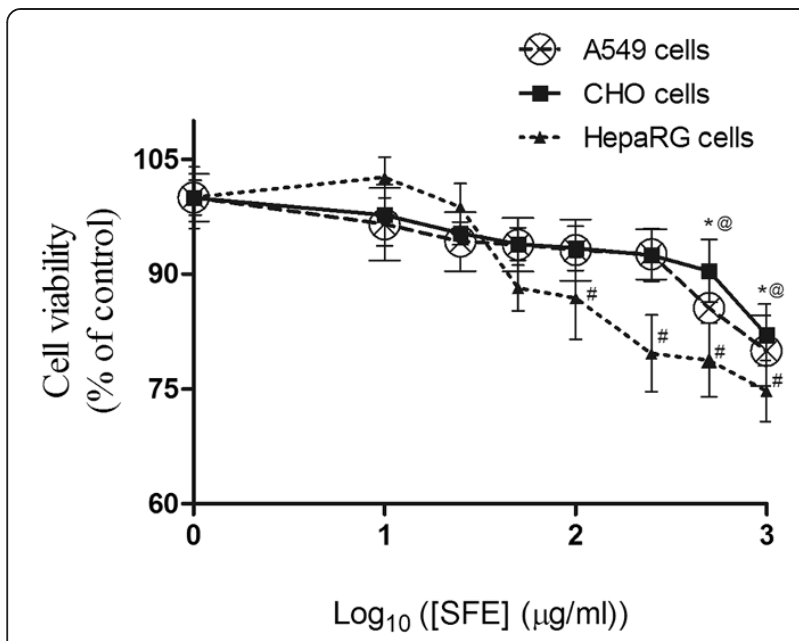

Figure 7 Dose response curves to compare the effects of SFE on cell viability in A549, CHO, and HepaRG cell lines. These cell lines were treated with various doses of SFE for $24 \mathrm{~h}$ and viability was determined by Calcein AM assay. Values represent mean \pm SD $(n=5)$.

for subsequent experiments to study the protective effect of SFE on tBHP-induced GSH depletion.

\section{Effect of SFE on intracellular ROS levels}

To test the hypothesis that SFE combat oxidative stress by scavenging ROS, we measured ROS levels after the

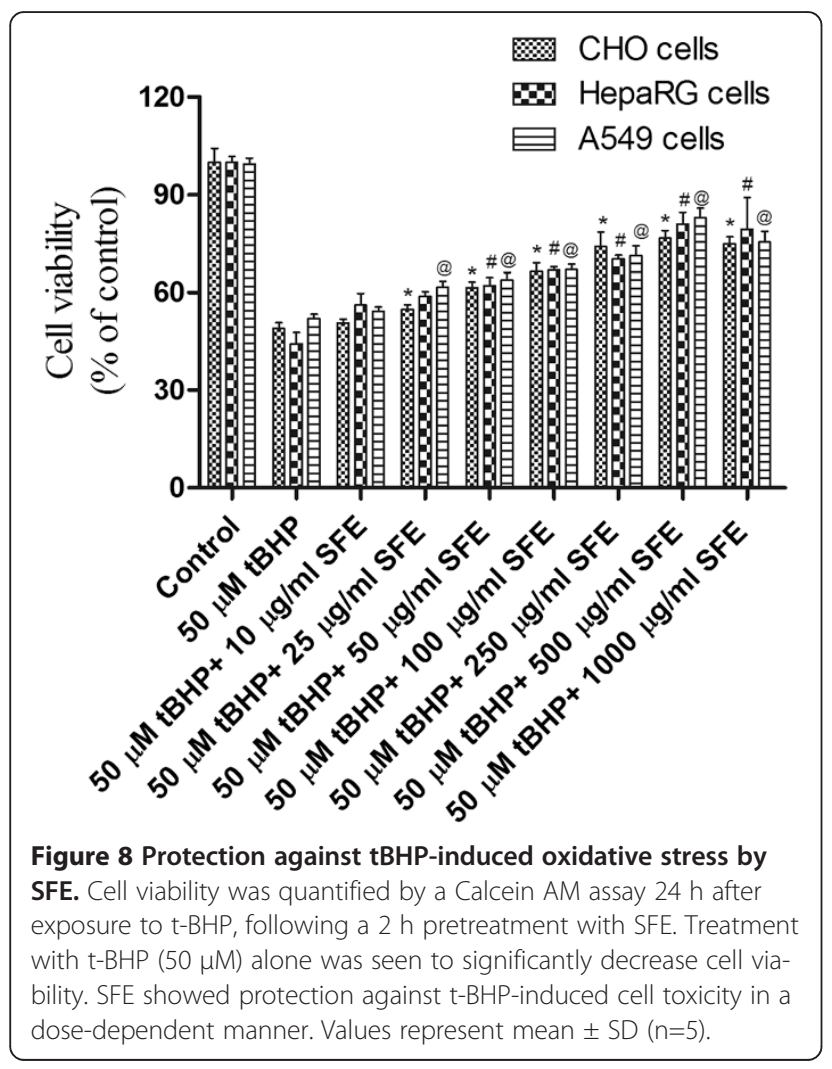

exposure of cells to $50 \mu \mathrm{M}$ t-BHP for $2 \mathrm{~h}$. A dose dependent increase in the production of ROS was observed in all three cell lines with exposure to tBHP (data not shown). To study the protective effects of SFE on a tBHP-induced increase in ROS levels, all three cell lines were pretreated with various concentrations of SFE for 2 h, followed by incubation with $50 \mu \mathrm{M}$ of tBHP for $2 \mathrm{~h}$. There was a significant dose dependent decrease in levels of ROS with an increase in the concentration of SFE (Figure 9).

\section{Effect of SFE on intracellular glutathione levels}

To examine whether SFE acts as an antioxidant by scavenging ROS, thereby preventing further GSH depletion, we measured the levels of intracellular GSH. Figure 10 shows the effect of tBHP on intracellular GSH levels in the presence and absence of a SFE. A 24 h exposure with $50 \mu \mathrm{M}$ of tBHP decreased the GSH level by more than $50 \%$ of that of the control in all the three cell lines studied. Pretreatment with $500 \mu \mathrm{g} / \mathrm{ml}$ of SFE increased the GSH level significantly in all three cell lines (Figure 10).

\section{Effect of SFE on glutathione disulfide levels and GSH/ GSSG ratio}

The GSH/GSSG ratio decreased significantly upon treatment with $50 \mu \mathrm{M}$ t-BHP in all three cell lines. However, pretreatment with $500 \mu \mathrm{g} / \mathrm{ml}$ of SFE significantly decreased the level of GSSG and increased the ratio of GSH/GSSG to approximately that of the control group (Figure 11).

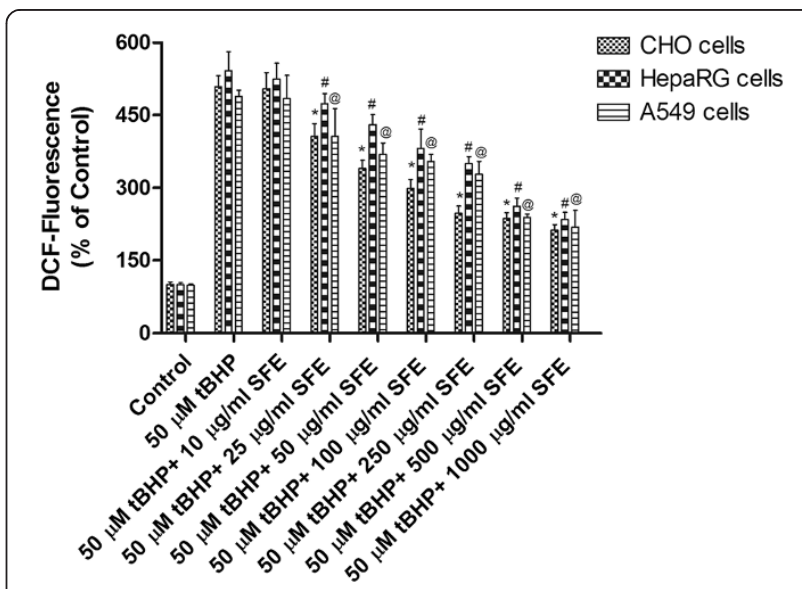

Figure 9 Intracellular ROS levels. ROS levels after pretreatment with various concentrations of SFE for $2 \mathrm{~h}$ followed by treatment with t-BHP $(50 \mu \mathrm{M})$ for $\mathbf{2 h}$. Treatment with $50 \mu \mathrm{M}$ t-BHP significantly increased the ROS levels. Pretreatment with SFE decreased the ROS levels in a dose-dependent manner. Values represent mean $\pm S D(n=5)$. 


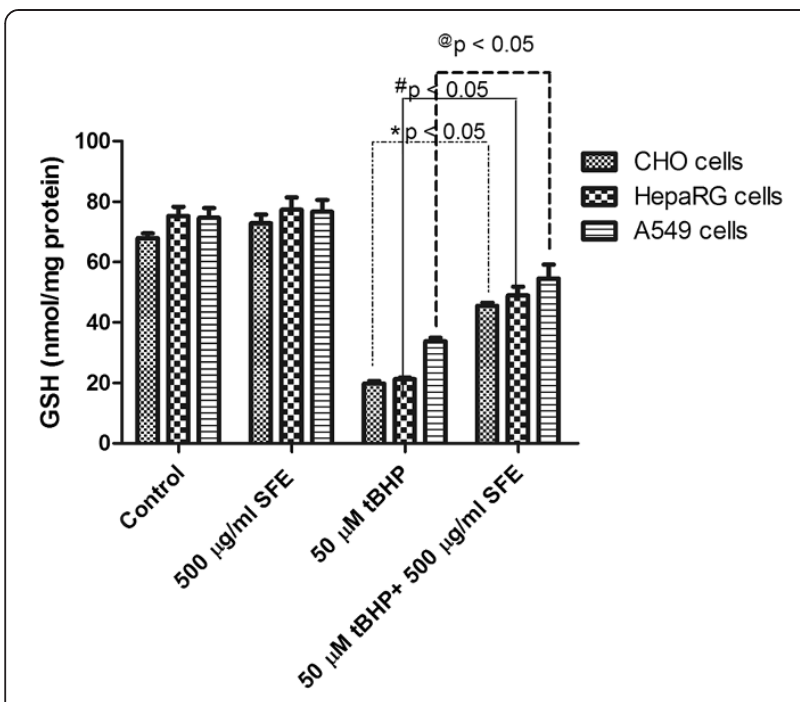

Figure 10 Intracellular GSH levels in A549, HepaRG, and CHO cells after treatment with $50 \mu \mathrm{M}$ t-BHP and $500 \mu \mathrm{g} / \mathrm{ml} \mathrm{SFE}$. GSH levels were measured after $24 \mathrm{~h}$ of treatment for control, SFE, t-BHP, and t-BHP + SFE groups. Exposure to t-BHP $(50 \mu \mathrm{M})$ significantly decreased intracellular GSH level. Pretreatment with SFE $(500 \mu \mathrm{g} / \mathrm{ml})$ $2 \mathrm{~h}$ before the addition of t-BHP, prevented such a dramatic decrease. ${ }^{*} p \leq 0.05$ compared to t-BHP group.

\section{Discussion}

Aspects of the antioxidant role of SF have been studied previously [12-14]; however, an extensive study comparing the antioxidant potential of different solvent extracts of SF in a cell-free system and in cell lines has not been

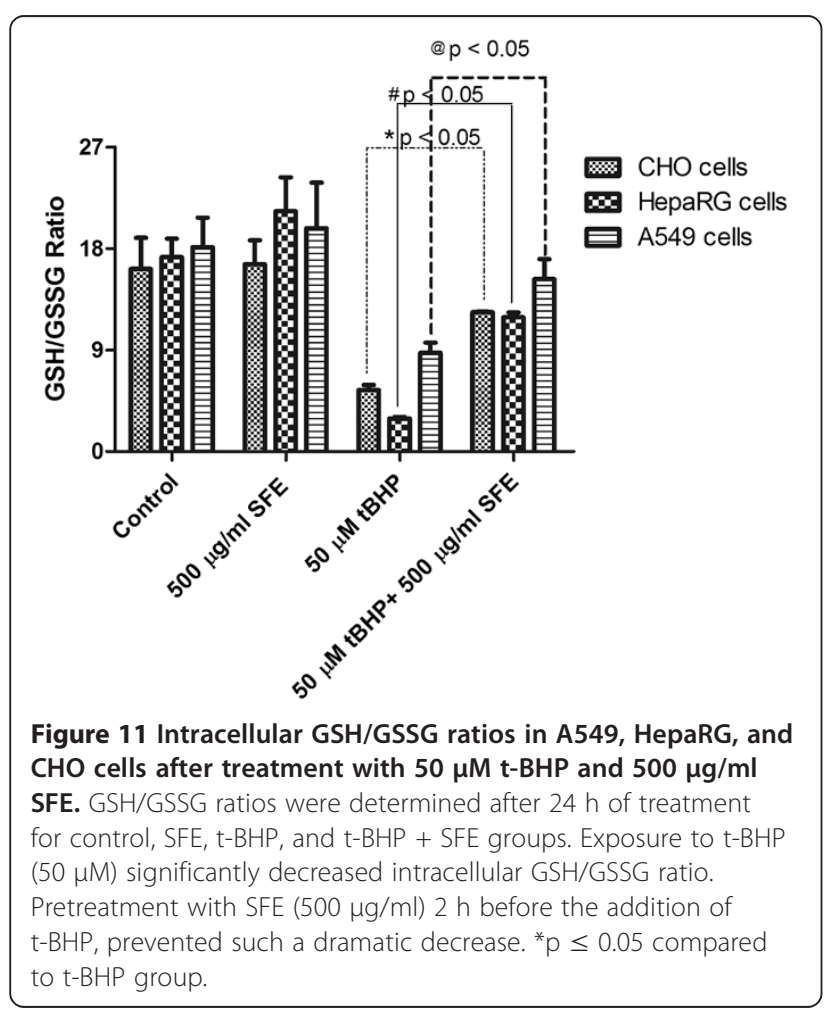

reported. Here, we report the antioxidant potential of SF extracts as well as their protective role in $\mathrm{t}$-BHP-induced oxidative stress in three cell lines.

The extracting solvent significantly affected the total phenolic content, flavonoid content, reducing power, and the radical scavenging activity of SF extracts. The yield of SF hot water extract was about 5\% (weight of lyophilized extract/weight of dried plant material). Polarity of the solvent affected the antioxidant potential of the extracts with hot water being the best solvent for extracting total phenolics, including flavonoids. Our results are similar to those of Katerere and Eloff, who investigated the antibacterial and antioxidant activity of SF using two different extraction schemes. They reported substantial radical scavenging activity in the more polar extracts, attributed to the polar phenolic compounds [13]. Contrary to this, Koleva et al. reported the highest radical scavenging activity in the methanol, ethyl acetate, and 1-butanol extracts and lowest in the aqueous extract, which was attributed to the origin of the plant sample and not the solvent polarity. Their semiquantitative TLC tests showed smaller amounts of phenolic components in these more polar extracts [14].

Our results indicate that SF plant extract contains significant amounts of flavonoids, whose mechanism of action is through scavenging or chelation [30]. It appears that hot water extract has the highest radical scavenging power, and is more powerful than the BHT standard, considering that the actual yield of hot water extract is $5 \%$ (20 mg of dried plant material yield $1 \mathrm{mg}$ of the lyophilized hot water extract). However, it does not show good reducing power and it appears that the superior radical scavenging capacity of hot water extract might provide it with significant antioxidant properties.

Superoxide anion, together with its dismutation product, hydrogen peroxide, is deleterious to macromolecules [31]. Flavonoids are effective scavengers of superoxide anions and thereby protective against oxidative damage [8]. Our results suggest that SF extract is a potent scavenger of superoxide radicals and hydroxyl radicals. Hydroxyl radicals are one of the major reactive oxygen species produced as a result of Fenton's reaction, causing lipid peroxidation and subsequent cellular damage [26]. Hot water plant extract proved to be the most potent scavenger of hydroxyl radicals, followed by superoxide anion radical and then hydrogen peroxide. However, it did not exhibit considerable nitric oxide scavenging ability. Our results concur with Fernandes et al., who reported that extracts from hot water demonstrated superoxide and hydrogen peroxide scavenging activity, and attributed the antioxidant activity of SF hot water extract to the phenolic compounds [12].

Iron can stimulate lipid peroxidation via Fenton reaction and also by decomposing lipid hydroperoxides into 
peroxyl and alkoxyl radicals that can further propagate the chain reaction [29]. According to our results, the metal chelating activity of SF extract is not as good as the standard EDTA and, therefore, its antioxidant potential could be attributed primarily to its radical scavenging power. Differences in the antioxidant potential of extracts of SF could be attributed to the differences in the composition of the extracts in those solvents.

SFE were not toxic to $\mathrm{CHO}$ and A549 cells below a concentration of $500 \mu \mathrm{g} / \mathrm{ml}$. However, mild toxicity was observed above $100 \mu \mathrm{g} / \mathrm{ml}$ for HepaRG cells, which could be due to the differences in the cells and their susceptibility to SFE. SFE protected cells against t-BHPinduced oxidative stress and increased cell viability in a dose-dependent manner up to $0.5 \mathrm{mg} / \mathrm{ml}$. However, no further increase in cell viability was observed above this concentration. Our results are in line with Fernandes et al. who reported that SF hot water extract, up to concentrations of $40 \mu \mathrm{g} / \mathrm{ml}$, had no adverse effect on the viability of human neutrophils after a $30 \mathrm{~min}$ treatment [12]. Our results are also supported by another study on proximal and distal convoluted tubule epithelial cell lines (LLC-PK1 and MDBK), in which the cell viability of both cell lines treated with concentrations between 6 $\mathrm{mg} / \mathrm{ml}$ and $0.3 \mathrm{mg} / \mathrm{ml}$ for $48 \mathrm{~h}$ was more than $89 \%$ [32]. Results from Ngcobo et al. are similar to our results where they showed that although high concentrations of SF extracts (ethanol) can be toxic to normal $\mathrm{T}$ cells, SFW (water) fractions were relatively non-toxic. They found that $0.5 \mathrm{mg} / \mathrm{ml} \mathrm{SFW}$ extract showed $81 \%$ live cells after $24 \mathrm{~h}$ [33]. In addition, safety studies in vervet monkeys and humans have suggested that SF extracts are not toxic $[34,35]$.

In contrast, some studies have shown cytostatic and cytotoxic effects of SF extracts in cervical carcinoma cells, Chinese hamster ovary cancer cells, Caski and Jurkat T Lymphoma cells, human breast adenocarcinoma (MCF-7), human non-tumorigenic epithelial mammary gland cells (MCF-12A), MDA-MB-468 cell line, human leukemia Jurkat cells, human promyelocyte HL60 cells, MDA-MB231 breast cancer cells, DU-145 prostate cancer cells, and proximal and distal convoluted tubule epithelial cell lines (LLC-PK1 and MDBK) [32,36-39].

These contrasting results could be due to a variety of factors such as differences in cell lines, preparation of extracts (tablets vs. dried plant parts), the extraction solvent, dosage concentrations and times, as well as varying components in plants grown in regions with different soil compositions and environmental factors (leading to synthesis and accumulation of secondary metabolites) [40].

Our results showed that SFE protected cells by scavenging ROS in a dose dependent manner in all three cell lines. These results are also in line with Fernandes et al., who reported that the SF hot water extract significantly decreased both the luminal and lucigenin enhanced chemiluminescence responses of neutrophils stimulated by FMLP in a dose related manner [12].

To further elucidate the mechanism of protection against t-BHP-induced oxidative stress, GSH and GSSG levels were measured. GSH, in its reduced form, is the most powerful intracellular antioxidant and the ratio of reduced to oxidized glutathione (GSH/GSSG) is representative of the antioxidative capacity of the cell. An increase in ROS, together with a decrease in GSH, sets off a cascade of further oxidative damage. SFE was able to prevent depletion of GSH in all the three cell lines. Our results are supported by a study done by Ngcobo [41] where the SF extracts decreased both cell viability and GSH levels in H9 cancerous cells while the same extracts significantly increased cell viability and GSH levels in normal $\mathrm{T}$ cells. The extracts caused a time-dependent decrease in GSH content in H9 cells with the SF water extract dilutions being more effective than the ethanol extracts. However, in normal $\mathrm{T}$ cells, the extracts negatively affected the levels of GSH at higher concentrations but enhanced the GSH content at lower concentrations. The SF water extract dilutions were also more effective in increasing the GSH content of normal $\mathrm{T}$ cells than the ethanol extracts. However, contrary to this, a significant decrease in GSH was reported in SF-treated MDBK cells and LLC-PK1 cells [32]. These contrary results could, again, be due to differences in cell lines, doses, incubation times, as well as extract preparation.

\section{Conclusion}

Our results indicate that hot water is a better solvent for the extraction of the antioxidant ingredients of SF vegetative material. Flavonoids may be the key component responsible for the antioxidant potential of SF based on its superior radical scavenging ability. In addition, protection against $\mathrm{t}$-BHP-induced oxidative stress in transformed as well as normal cell lines further demonstrates its antioxidant potential. In vitro assays indicate that this plant extract is a significant source of natural antioxidants, which might be helpful in preventing the progression of various oxidative stresses.

\section{Competing interests}

The authors declare that they have no competing interests.

\section{Authors' contributions}

ST designed, analyzed, and wrote the manuscript. WF conducted most of the experiment. CJH conducted some of the experiments. NE and WRF revised the paper critically for important intellectual content. All authors have seen and approved the manuscript.

\section{Acknowledgements}

The authors appreciate the efforts of Barbara Harris in editing the manuscript. Dr. Ercal is supported by Richard K. Vitek endowment and Dr. 
Folk is supported by NIH P50 AT006273. The views are solely those of the authors and not the sponsors.

\section{Author details}

'Department of Chemistry, Missouri University of Science and Technology, 400 West 11th Street, 142 Schrenk Hall, Rolla, MO 65409, USA. ²Department of Biochemistry, University of Missouri, Columbia, MO 65211, USA.

Received: 14 April 2014 Accepted: 22 July 2014

Published: 29 July 2014

\section{References}

1. Hayes JD, McLellan LI: Glutathione and glutathione-dependent enzymes represent a co-ordinately regulated defence against oxidative stress. Free Radic Res 1999, 31:273-300.

2. Nakabeppu Y, Tsuchimoto D, Furuichi M, Sakumi K: The defense mechanisms in mammalian cells against oxidative damage in nucleic acids and their involvement in the suppression of mutagenesis and cel death. Free Radic Res 2004, 38:423-429.

3. Papas AM: Diet and antioxidant status. Food Chem Toxicol 1999, 37:999-1007.

4. Morel I, Lescoat G, Cillard P, Cillard J: Role of flavonoids and iron chelation in antioxidant action. Methods Enzymol 1994, 234:437-443.

5. Rice-Evans C: Flavonoid antioxidants. Curr Med Chem 2001, 8:797-807.

6. Krinsky NI: Mechanism of action of biological antioxidants. Proc Soc Exp Biol Med 1992, 200:248-254.

7. van $W y k B E$, Albrecht $C$ : A review of the taxonomy, ethnobotany, chemistry and pharmacology of Sutherlandia frutescens (Fabaceae). J Ethnopharmacol 2008, 119:620-629.

8. Robak J, Gryglewski RJ: Flavonoids are scavengers of superoxide anions. Biochem Pharmacol 1988, 37:837-841.

9. Chen JW, Zhu ZQ, Hu TX, Zhu DY: Structure-activity relationship of natural flavonoids in hydroxyl radical-scavenging effects. Acta Pharmacol Sin 2002, 23:667-672.

10. Rice-Evans C, Packer L: Flavonoids in health and disease. New York: Marcel Dekker; 1998.

11. Fu X, Li XC, Wang YH, Avula B, Smillie TJ, Mabusela W, Syce J, Johnson Q, Folk W, Khan IA: Flavonol glycosides from the south African medicinal plant Sutherlandia frutescens. Planta Med 2010, 76:178-181.

12. Fernandes $A C$, Cromarty AD, Albrecht $C$, van Rensburg CE: The antioxidant potential of Sutherlandia frutescens. J Ethnopharmacol 2004, 95:1-5.

13. Katerere DR, Eloff JN: Antibacterial and antioxidant activity of Sutherlandia frutescens (Fabaceae), a reputed anti-HIV/AIDS phytomedicine. Phytother Res 2005, 19:779-781.

14. Koleva II, van Beek TA, Linssen JP, de Groot A, Evstatieva LN: Screening of plant extracts for antioxidant activity: a comparative study on three testing methods. Phytochem Anal 2002, 13:8-17.

15. Konaté K, Kiendrébéogo M, Ouattara MM, Souza A, Lamien-Meda A, Nongasida Y, Barro N, Millogo-Rasolodimby J, Nacoulma OG: Antibacterial potential of aqueous acetone extracts from five medicinal plants used traditionally to treat infectious diseases in burkina faso. Curr Res J Biol Sci 2011, 3:8.

16. Kalava $V$, Menon $S$ : In-vitro free radical scavenging activity of aqueous extract from the mycella of volvariella volvacea (bulliard ex fries) singer. Int J Current Pharmaceutical Res 2012, 4:7.

17. Jayanthi P, Lalitha P: Reducing Power of the solvent extracts of eichhornia crassipes (Mart.) solms. Int J Pharmacy Pharmaceutical Sci 2011, 3:3.

18. Shyamala S, Vasantha K: Free radical scavenging and antioxidant activity of leaves from Agathi (Sesbania grandiflora) (L.) Pers. Am Eurasian J Sci Res 2010, 5:6.

19. Ozyurek M, Bektasoglu B, Guclu K, Gungor N, Apak R: A novel hydrogen peroxide scavenging assay of phenolics and flavonoids using cupric reducing antioxidant capacity (CUPRAC) methodology. J Food Compos Anal 2010, 23:10

20. Pramod K, Devala RG, Lakshmayya B, Ramachandra SS: Nephroprotective and nitric oxide scavenging activity of tubers of momordica tuberosa in rats. Avicenna J Med Biotechnol 2011, 3:87-93.

21. Bajpai VK, Sharma A, Kang SC, Baek KH: Antioxidant, lipid peroxidation inhibition and free radical scavenging efficacy of a diterpenoid compound sugiol isolated from Metasequoia glyptostroboides. Asian Pac J Trop Med 2014, 7:9-15.
22. Kunchandy E, Rao MNA: Oxygen radical scavenging activity of curcumin. Int J Pharm 1990, 58:4.

23. Manda K, Adams C, Ercal N: Biologically important thiols in aqueous extracts of spices and evaluation of their in vitro antioxidant properties. Food Chem 2010, 118:5.

24. Bradford MM: A rapid and sensitive method for the quantitation of microgram quantities of protein utilizing the principle of protein-dye binding. Anal Biochem 1976, 72:248-254.

25. Wang B-J, Lien Y-H, Yu Z-R: Supercritical fluid extractive fractionation study of the antioxidant activities of propolis. Food Chem 2004, 86:7

26. Stohs SJ, Bagchi D: Oxidative mechanisms in the toxicity of metal ions. Free Radic Biol Med 1995, 18:321-336.

27. Marcocci L, Maguire JJ, Droy-Lefaix MT, Packer L: The nitric oxide-scavenging properties of Ginkgo biloba extract EGb 761. Biochem Biophys Res Commun 1994, 201:748-755

28. Wink DA, Kasprzak KS, Maragos CM, Elespuru RK, Misra M, Dunams TM, Cebula TA, Koch WH, Andrews AW, Allen JS, Keefer LK: DNA deaminating ability and genotoxicity of nitric oxide and its progenitors. Science 1991, 254:1001-1003.

29. Halliwell B: Reactive oxygen species in living systems: source, biochemistry, and role in human disease. Am J Med 1991, 91:14S-22S.

30. Cook N, Samman S: Flavonoids-Chemistry, metabolism, cardioprotective effects, and dietary sources. J Nutr Biochem 1996, 7:11.

31. Benov L: How superoxide radical damages the cell. Protoplasma 2001, 217:33-36.

32. Phulukdaree A, Moodley D, Chuturgoon A: The effects of Sutherlandia frutescens extracts in cultured renal proximal and distal tubule epithelial cells. S Afr J Sci 2010, 106:5.

33. Ngcobo M, Gqaleni N, Chelule PK, Serumula M, Assounga A: Effects of Sutherlandia frutescens extracts on normal T-lymphocytes in vitro. Afr J Tradit Complement Altern Med 2012, 9:73-80.

34. Seier JV, Mdhluli M, Dhansay M, Loza J, Laubscher R: A toxicity study of Sutherlandia leaf powder (Sutherlandia microphylla) consumption. Medical Research Council, National Research Foundation (NRF) of South Africa 2002, 1-35.

35. Johnson Q, Syce J, Nell H, Rudeen K, Folk WR: A randomized, double-blind, placebo-controlled trial of Lessertia frutescens in healthy adults. PLoS Clin trials 2007, 2:e16.

36. Stander A, Marais S, Stivaktas V, Vorster C, Albrecht C, Lottering ML, Joubert AM: In vitro effects of Sutherlandia frutescens water extracts on cell numbers, morphology, cell cycle progression and cell death in a tumorigenic and a non-tumorigenic epithelial breast cell line. J Ethnopharmacol 2009, 124:45-60.

37. Tai J, Cheung S, Chan E, Hasman D: In vitro culture studies of Sutherlandia frutescens on human tumor cell lines. J Ethnopharmacol 2004, 93:9-19.

38. Chinkwo KA: Sutherlandia frutescens extracts can induce apoptosis in cultured carcinoma cells. J Ethnopharmacol 2005, 98:163-170.

39. Vorster C, Stander A, Joubert A: Differential signaling involved in Sutherlandia frutescens-induced cell death in MCF-7 and MCF-12A cells. J Ethnopharmacol 2012, 140:123-130.

40. Wink M, Wiley InterScience (Online service): Functions And Biotechnology Of Plant Secondary Metabolites. In Book Functions And Biotechnology Of Plant Secondary Metabolites. 2nd edition. Wiley-Blackwell; 2010

41. Nycobo M: The biochemical effects of Sutherlandia Frutescens in cultured H9 cancerous T cells and normal human T lymphocytes. In MMedSci Thesis, University of KwaZulu-Natal; 2008.

doi:10.1186/1472-6882-14-271

Cite this article as: Tobwala et al: Antioxidant potential of Sutherlandia frutescens and its protective effects against oxidative stress in various cell cultures. BMC Complementary and Alternative Medicine 2014 14:271. 